\title{
AN EVALUATION OF SAFETY RISK FACTORS DURING INSTALLATION AND DISMANTLING OF TOWER CRANES IN CONSTRUCTION SITES
}

\author{
A. A. Salihu ${ }^{1, *}{ }^{*}$, S. S. Aliyu ${ }^{2}$ and M. Abubakar ${ }^{3}$ \\ 1, 2, 3, Department of Building, AhMAdu Bello University, ZARIA, KadunA STATE, NIGERIA \\ Email addresses: 1 ibnsaliha@gmail.com, 2 asshika1@gmail.com, \\ 3 muawiyaabubakar1@gmail.com
}

\begin{abstract}
The construction industry plays a central and significant role in the economy of any nation. One of the major reasons for ineffective project delivery in the Nigerian construction industry is the improper assessment of risk factors. The industry however is currently facing a lot of challenges which include constant increase in the rate of accidents on construction sites which could be due to ineffective safety management as construction companies are usually interested in maximizing their profit in order to secure funds for new investments, and cover possible expenses associated with the occurrence of risk factors during construction. Installation and dismantling of tower crane had been previously looked at as a general safety issue until, recent research showed that about 69\% of accidents related to tower cranes in Korea from 2001-2011, occur during installation and dismantling process. In view of this, this paper aimed at evaluating safety risk factors during installation and dismantling by determining their probability of occurrence and degree of impact with a view to establishing the most significant ones. This is why a well-structured questionnaire was designed to collect data with respect to their probability of occurrence and degree of impact using a 5 point Likert scale. Responses from the administered questionnaire and interactions were collated, interpreted and analysed using descriptive statistics (mean) and results presented in tables. Results showed that abrasion (wear and tear of components such as bolts, nuts, or pins) is the most probable factor with a mean value of 3.63. Fracture of a wire rope during dismantling had the highest degree of impact with a mean value of 4.63. The research concluded that fracture of a wire rope during dismantling and abrasion (wear and tear of components such as bolts, nuts, or pins) are highly affecting factor on safety during installation and dismantling. Adoption of a preventive maintenance strategy or routine check on the tower crane parts and components could help minimize the probability of occurrence and impact of the safety risk factors on site.
\end{abstract}

Keywords: Accident, Hazard, Safety risk, Tower crane, Probability, Construction industry.

\section{INTRODUCTION}

Tower cranes are used on construction sites as lifting equipment for their combination of height and lifting capacity. Tower crane accidents, however, are likely to be fatal because of the weight of the objects and the heights to which they are lifted [1]. United States labour statistics recorded 632 crane-related construction worker deaths from 611 crane incidents and 17 multiple death incidents resulting in 38 deaths from 1992 to 2006 [2]. A crane safety analysis and recommendation report carried out in Singapore by [3] indicates that in 2008, there were 162 crane-related fatalities, injuries and dangerous occurrences, a $27 \%$ increase from 128 cases in 2007. While most of the cases involve less serious non-fatal injuries, crane accidents can ultimately result to huge and severe damage to physical properties and human lives.

\footnotetext{
* Corresponding author: +234-905 - 554-0012
} 
Idoro [4] posit that construction processes in Nigeria are characterized by unsafe practices leading to accident that leaves severe consequences on both the project and the workers. Accidents in building construction sites, whether minor or fatal could result to injuries, loss of resources, partial or permanent disability and death in case of fatalities. In his analysis of types of accident that usually occur in construction sites, injury from the use of equipment ranked first among nine (9) other types of accident examined. Accidents frequently occur on building construction sites, these accidents could be in the form of workers falling from heights, excavation accidents, the risk of falling debris or equipment's and so forth. Researches have shown that accidents and injuries in developing countries are generally high when compared to other European countries [5].

Effective safety management is to make the environment safe, to make the job safe and to make workers safety conscious. In recent years, many developed countries have considered safety as one of the important management issues of construction projects, especially, personal safety [6].

Ali and Muhammad [7] opines that without proper safety management of construction machines at construction sites, accidents could happen. Cranes are the machines that contribute to highest fatality rate in the construction industry. He concludes that cranes are machines with high risk and should be operated with safety management and strong communication between crane operator and signalman.

Factors that affect construction site safety due to the work of tower cranes have attracted only moderate attention; they are commonly addressed indirectly and partially within the broader treatment of site safety or of crane work in general [8]. Literature addressing crane safety that explicitly suggests tower crane related risk factors or safety hazards is limited [9]. Hence the need to critically examine safety issues regarding the installation/dismantling operation of tower cranes.

The objectives of this research are:

i. To determine the probability of occurrence and degree of impact of safety risk factors during installation and dismantling of tower cranes in construction sites.

ii. To evaluate the safety risk factors based on established risk rating scales.
Safety risk factors during the operation of tower cranes were not considered for this study, only those associated with the process of installation and dismantling of tower cranes were considered.

\section{LITERATURE REVIEW}

The consequences of building construction accidents are enormous and cannot be easily quantified, though inevitable but could be controlled to prevent minor or serious consequences to safety of workers [4].

Idoro [10] asserted that although there is no reliable construction accident/incident data in Nigeria. However, a study of 40 contractors in 2006 revealed that accident and injury rates were high in the Nigerian construction industry and the best safety ratios were 2 accidents per 100 workers and 5 injuries per 100 workers. Kadiri, et. al [11] stated that as the growth of construction industry blossoms in Nigeria, this also causes an increase in competition of projects to execute between construction firms which are however achieved at the expense of the workers welfare and their safety. Therefore identifying the various causes and effect of accidents on construction sites and proposing ways and means of reducing these accidents should be acknowledged.

Erection/climbing/dismantling of tower cranes is a potentially hazardous process involving working at heights, awkward postures, lifting and aligning components of significant size and mass and installing temporary support systems. These are all often performed under significant time pressure due to the need for road closures, suitable daylight hours or short weather windows as the case maybe [12]. The most dangerous process that can lead to fatalities at construction sites is the installation/dismantling of tower cranes; for instance, in 2012, the collapse of a tower crane during dismantling at the University of Texas, USA claimed the lives of two workers [13]. There have been five fatal accidents relating to tower crane use during 2002-2006 in Hong Kong, with three workers being killed in July 2007 alone. One such accident in July 2007 caused two fatalities and five serious injuries. The accident happened during the dismantling process, with workers on the tower crane as it crashed down [14]. Also in a related development, out of the 571 incident cases of crane related accidents that happened from $2000-2009$ in the U.S as examined by [15], 41 cases which 
amounted to $7.18 \%$ occurred during assembly/disassembly. He further went ahead to say that 22 cases $(23.40 \%)$ of the 94 cases that occurred from 2007-2009 resulted directly from the operations of assembly/disassembly. More recently, is an investigation of tower crane accidents that occurred in Korea from 2001-2011, it was reported that out of the 38 fatal accident cases involving tower cranes, $68.4 \%$ of the accidents resulted from the installation/dismantling operation [16].

Chi, et al. [17] opined that, risk identification and cautioning can improve the safety of workplaces. By organizing high recurrence risk factors to viably control accident occurence and deal with the probability of lethal injuries on construction sites when an accident is unavoidable, enables/helps safety managers to comprehend the nature of construction accidents and plan for key risk mitigation.

However, [18] having concerted for the fact that assessment of risk is crucial for improving safety, went ahead to say that precise evaluation is not really necessary and that an estimated predicted level of risks will suffice for the safety managers to take necessary actions.

\subsection{Safety Risk Factors during Installation and Dismantling of Tower Cranes:}

Not much has been done by researchers to clearly identify various factors affecting safety during installation and dismantling operation of tower cranes especially in Nigeria where construction site safety is very poor and accidents on construction sites are rarely reported nor documented for use as contractors are simply concerned with making maximum profit [19]. However, according to [13] accidents may occur during crane erection, dismantling and height alteration operations due to failure to follow the correct procedures specified by the crane manufacturers, use of incorrect parts, the wrong size or type of bolt, the incorrect assembly or sequence of assembly, or taking apart of components. Shin [16] also identified some risk factors affecting safety during installation and dismantling process in construction sites to include insufficient numbers of workers to perform the work correctly and safely, trying to finish the work earlier than the time required for safe work, frequently omitting required safety procedures or rules for various reasons and lack of worker competence. More recently, is the study by [20] where they reviewed all risk factors associated with tower crane installation and dismantling process and came up with a list of safety risk factors as shown in Table 1.

\section{RESEARCH METHODOLOGY}

The study looks at probability/likelihood of occurrence and impact of safety risk factors with respect to determining there frequency of occurrence and degree of impact respectively.

This requires eliciting knowledge from practitioners who are directly involved in the process such as safety managers, equipment managers and team leaders of installation and dismantling workers. Hence, questionnaire survey was adopted. Population size for the research was unknown as no data is available on exact number of these practitioners. The sample size was determined from a table developed by [21] that the minimum sample size for an unknown population for $95 \%$ confidence interval with $5 \%$ error level is approximately 34 . A total of 57 questionnaires were generated and distributed in Kaduna, Abuja and Lagos using purposive sampling technique.

Table 1: Safety risk factors, Source [20]

$\mathrm{S} /$ No. Safety risk factors during installation and dismantling

1 Insufficient number of workers to perform the work correctly and safely.

$2 \quad$ Workers (erector, dismantler) are leaving the work

2 often due to hard working condition).

3 Time constraints requested from employer/principal contractor.

4 Trying to finish the work earlier than the time required for safe work.

5 Frequently omitting required safety procedures or

rules for various reasons.

$6 \quad$ Lack of workers competence.

7 Instruction and supervision at construction sites are

insufficient.

8 Contractors do not recognize the need to ensure

the safety tower crane installation/dismantling.

9 Unreasonable sites condition (working space, ground conditions and restrictions).

10 Deterioration of tower cranes part (components).

11 Workers attitude (installation/dismantling workers). Overloading with objects exceeding the tower crane load limit.

13 Inexperienced tower crane operators.

14 Not following work procedures in manuals for the

installation/climbing/dismantling of tower cranes.

15 Malfunction of a tower crane.

16 Buckling of a telescopic cage.

17 Fracture of a wire rope during dismantling. 


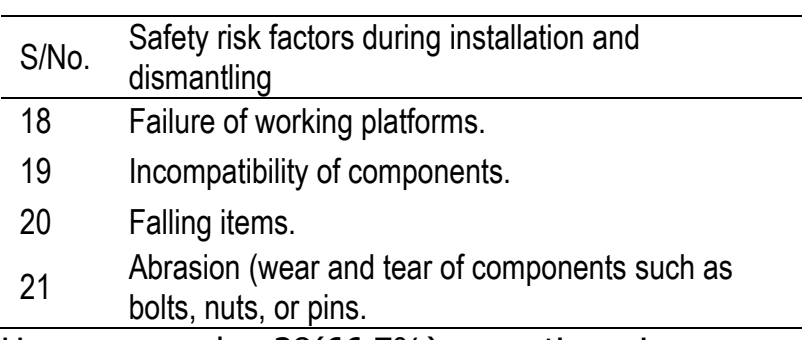
However, only $38(66.7 \%)$ questionnaires were analysed using descriptive statistics and results presented in tables.

\section{FINDINGS AND DISCUSSION}

\subsection{Respondents Profile:}

This section presents the personal details of the respondents to include; their nature of job, educational qualification and years of experience as presented in Table 2.

Table 2 indicates that all the categories of respondents are adequately represented having at least $\approx 30 \%$ representation each with safety managers having a higher representation of $36.8 \%$ and equipment managers having the least representation of $28.9 \%$. All the respondents had at least a post-secondary education with $13(34.2 \%)$ of them having a bachelors and $6(15.8 \%)$ had MSc. Table 4.1 also shows that $34.2 \%$ of the respondents had between 0-5 years of experience. A cumulative of $65.8 \%$ of the respondents have at least 6years of experience working in tower crane environment and were therefore able to make correct and valid judgement.

Table 2: Respondents profile

\begin{tabular}{lcc}
\hline Items & $\begin{array}{c}\text { Frequency } \\
\text { (No }\end{array}$ & $\begin{array}{c}\text { Percentage } \\
(\%)\end{array}$ \\
\hline Job description & & \\
Safety managers & 14 & 36.8 \\
Equipment managers & 11 & 28.9 \\
Installation and dismantling & 13 & 34.2 \\
workers & 38 & 100 \\
Total & & \\
Educational qualification & 12 & 31.6 \\
ND & 7 & 18.4 \\
HND & 13 & 34.2 \\
Bachelors & 6 & 15.8 \\
MSc. & 38 & 100 \\
Total & & \\
Years of experience & 13 & 34.2 \\
0-5 & 20 & 52.6 \\
6-10 & 4 & 10.5 \\
11-15 & 1 & 2.6 \\
16-20 & 38 & 100 \\
Total & & \\
\hline
\end{tabular}

\subsection{Probability of Occurrence for Safety Risk Factor}

The probability of occurrence for each safety risk factor were scored by the respondents based on a five point Likert scale. Mean values were determined and standard deviation also determined to help rank the factors that have the same mean value as shown in Table 3.

Table 3 presents the assessment of the probability of occurrence of each factor which shows that the most probable factor is "Abrasion (wear and tear of components such as bolts, nuts or pins)" with a mean value of 3.63 and the least probable factor is "Incompatibility of components" with a mean value of 2.16. However, the first six (6) factors as seen in Table 3 had mean values $\geq 3.0$ which means these factors have a possibility of occurring and may recur occasionally. The factors from $8^{\text {th }}$ position to $21^{\text {st }}$ had mean values $\geq 2.0$ which means these factors are unlikely to recur but, have the possibility of occurring. We can conclusively say that these results implies that all the identified factors have the possibility of occurring on our construction sites.

Researchers that previously looked at safety issues associated with tower crane installation and dismantling concluded that failure to follow work procedure is the most likely factor that can result to accidents on construction sites as stated by $[13,16]$. However, the results presented in Table 3 proved otherwise by ranking "not following work procedure in manuals" as $12^{\text {th }}$ position with a mean value of 2.89. This could imply that there have been an increased awareness and recognition of safety issues during installation and dismantling of tower cranes over the years which has made the users more safety conscious by implementing work procedures as stated in the manuals.

The most probable factor being "abrasion (wear and tear of components such as bolts, nuts, or pins)" has affirmed previous research finding that maintenance management is a highly affecting factor on safety when using tower cranes as stated by [9]. This implies that this factor yet plays a great influence on safety during installation and dismantling and/or during operation.

It is also interesting to note that operator proficiency or experience of the tower crane operator which has been widely accepted as the major safety determinant on site as cited by $[1,9,22]$ was ranked $4^{\text {th }}$ with a mean value of 3.18 . This implies that although it remains a probable factor according to

Vol. 39, No. 4, October 2020

995 
this study however, it has a greater influence on safety during the operation of tower crane. Another likely reason for this factor been ranked $4^{\text {th }}$ could be that operators had gained experience over the years thereby reducing its influence on safety as tower cranes are now widely used and becoming a culture in every construction environment. Incompatibility of components ranked the least amongst all other factors assessed which implies that tower crane manufacturers have continuously improved on the compatibility of their tower crane components. More efforts is still required to completely eliminate this factor as it is still a probable factor although not recurring frequently.

Table 3: Probability of occurrence

\begin{tabular}{|c|c|c|c|c|c|c|c|c|c|c|c|}
\hline \multirow{2}{*}{ S/No. } & \multirow{2}{*}{ Safety Risk Factors } & \multicolumn{6}{|c|}{ Frequency } & \multirow{2}{*}{$\sum_{\left(\sum \mathrm{fx}\right.}$} & \multirow{2}{*}{ Mean } & \multirow{2}{*}{ Std. Dev. } & \multirow{2}{*}{ Rank } \\
\hline & & 1 & 2 & 3 & 4 & 5 & $\sum f$ & & & & \\
\hline 1 & $\begin{array}{l}\text { Abrasion (wear and tear of components } \\
\text { such as bolts, nuts, or pins). }\end{array}$ & 0 & 9 & 9 & 7 & 13 & 38 & 138 & 3.63 & 1.19 & 1 st \\
\hline 2 & Fracture of a wire rope during dismantling. & 0 & 5 & 19 & 9 & 5 & 38 & 128 & 3.37 & 0.88 & $2^{\text {nd }}$ \\
\hline 3 & $\begin{array}{l}\text { Deterioration of tower cranes part } \\
\text { (components). }\end{array}$ & 3 & 4 & 11 & 19 & 1 & 38 & 125 & 3.29 & 0.98 & $3^{\text {rd }}$ \\
\hline 4 & Inexperienced tower crane operators. & 0 & 14 & 6 & 15 & 3 & 38 & 121 & 3.18 & 1.04 & $4^{\text {th }}$ \\
\hline 5 & Lack of workers competence. & 0 & 13 & 14 & 4 & 7 & 38 & 119 & 3.13 & 1.10 & $5^{\text {th }}$ \\
\hline 6 & $\begin{array}{l}\text { Trying to finish the work earlier than the } \\
\text { time required for safe work. }\end{array}$ & 1 & 9 & 19 & 5 & 4 & 38 & 116 & 3.05 & 0.96 & $6^{\text {th }}$ \\
\hline 7 & Buckling of a telescopic cage. & 1 & 9 & 22 & 3 & 3 & 38 & 112 & 2.95 & 0.87 & $7^{\text {th }}$ \\
\hline 8 & $\begin{array}{l}\text { Frequently omitting required safety } \\
\text { procedures or rules for various reasons. }\end{array}$ & 4 & 5 & 20 & 8 & 1 & 38 & 111 & 2.92 & 0.94 & $8^{\text {th }}$ \\
\hline 9 & Failure of working platforms. & 3 & 10 & 15 & 7 & 3 & 38 & 111 & 2.92 & 1.05 & $9^{\text {th }}$ \\
\hline 10 & Falling items. & 2 & 13 & 14 & 4 & 5 & 38 & 111 & 2.92 & 1.10 & $10^{\text {th }}$ \\
\hline 11 & $\begin{array}{l}\text { Not following work procedures in manuals } \\
\text { for the installation/climbing/dismantling of } \\
\text { tower cranes. }\end{array}$ & 4 & 5 & 21 & 7 & 1 & 38 & 110 & 2.89 & 0.92 & $11^{\text {th }}$ \\
\hline 12 & $\begin{array}{l}\text { Contractors do not recognise the need to } \\
\text { ensure the safety of tower crane } \\
\text { installation and dismantling. }\end{array}$ & 3 & 13 & 7 & 15 & 0 & 38 & 110 & 2.89 & 1.03 & $12^{\text {th }}$ \\
\hline 13 & $\begin{array}{l}\text { Workers (erector, dismantler) are leaving } \\
\text { the work often due to hard working } \\
\text { condition. }\end{array}$ & 5 & 11 & 15 & 3 & 4 & 38 & 104 & 2.74 & 1.13 & $13^{\text {th }}$ \\
\hline 14 & $\begin{array}{l}\text { Insufficient number of workers to perform } \\
\text { the work correctly and safely. }\end{array}$ & 3 & 17 & 8 & 8 & 2 & 38 & 103 & 2.71 & 1.06 & $14^{\text {th }}$ \\
\hline 15 & $\begin{array}{l}\text { Unreasonable sites condition (working } \\
\text { space, ground conditions and } \\
\text { restrictions). }\end{array}$ & 1 & 19 & 13 & 4 & 1 & 38 & 99 & 2.61 & 0.82 & $15^{\text {th }}$ \\
\hline 16 & $\begin{array}{l}\text { Time constraints requested from } \\
\text { employer/principal contractor. }\end{array}$ & 7 & 8 & 18 & 3 & 2 & 38 & 99 & 2.61 & 1.05 & $16^{\text {th }}$ \\
\hline 17 & Malfunction of a tower crane. & 7 & 17 & 6 & 4 & 4 & 38 & 95 & 2.50 & 1.22 & $17^{\text {th }}$ \\
\hline 18 & $\begin{array}{l}\text { Workers attitude (installation/dismantling } \\
\text { workers). }\end{array}$ & 4 & 17 & 13 & 3 & 1 & 38 & 94 & 2.47 & 0.89 & $18^{\text {th }}$ \\
\hline 19 & $\begin{array}{l}\text { Instruction and supervision at construction } \\
\text { sites are insufficient. }\end{array}$ & 10 & 12 & 11 & 3 & 2 & 38 & 89 & 2.34 & 1.12 & $19^{\text {th }}$ \\
\hline 20 & $\begin{array}{l}\text { Overloading with objects exceeding the } \\
\text { tower crane load limit. }\end{array}$ & 5 & 21 & 11 & 1 & 0 & 38 & 84 & 2.21 & 0.70 & $20^{\text {th }}$ \\
\hline 21 & Incompatibility of components. & 12 & 13 & 10 & 1 & 2 & 38 & 82 & 2.16 & 1.08 & $21^{\text {st }}$ \\
\hline
\end{tabular}

1=Rare $2=$ Unlikely $3=$ =Possible $4=$ Likely and $5=$ Almost certain. 


\subsection{Degree of Impact for Safety Risk Factors:} The impact of each factor were assessed using a five point Likert scale so as to establish their various levels of severity/degree of impact if they eventually occur on construction sites. The mean values were then calculated as shown in Table 4.

From Table 4, fracture of a wire rope during dismantling had the highest degree of impact with a mean value of 4.63 which implies that the resultant effect of this safety risk factor if it occur is fatality, major injury/injuries, permanent impairment, critical process loss and critical property damage. The factor "workers (erectors, dismantlers) are leaving the work often due to hard working condition" had the lowest degree of impact with a mean value of 2.34 which therefore implies that it's resultant effect if it occur can only lead to minor injury. All the factors however had degree of impact that range from minor injury to fatality as shown in Table 4. There is a need to pay serious attention on the first six factors as they have mean values $\geq 4.0$ which means if they occur, their resultant impact would lead to fatality on site.

Overloading tower cranes with objects exceeding its load limit is the $20^{\text {th }}$ probable factor to occur on site as seen from Table 3. However, results for degree of impact in Table 4. showed that it has a high degree of impact if its accident does happen on site as it was ranked $3^{\text {rd }}$ position amongst other factors with a mean value of 4.18 . The latter is in line with previous findings that exceeding tower crane load limit results to accident on site that could be very fatal involving multiple injuries in most cases. From a careful observation of this factor, one would notice a sharp distinction between its probability of occurrence and degree of impact. The reason for this could be linked to the previous assertion that there has been a significant improvement in the level of safety awareness on site as a result of continuous research on safety challenges associated with tower crane working environment thereby, reducing the probability of occurrence

\subsection{Evaluation of Safety Risk Factors}

The safety risk factors were evaluated by first determining their relative significant index score which is a function of the probability of occurrence and the degree of impact. The result of this was then measured against a standard risk rating developed by [23] so as to come up with their risk levels as shown in Table 5.

$\Sigma a$ (probability risk score), $\Sigma \beta$ (degree of impact risk score), $\Sigma \mathrm{RS}$ (combined risk score), N (population), RSIS (relative significance index score).

From Table 5, fracture of a wire rope during dismantling had the highest RSIS of 15.6 and implies a high risk factor which requires a high level of control put in place to forestall danger and make the working environment safer. The factors ranked from $2^{\text {nd }}$ to $15^{\text {th }}$ as shown in Table 5 had RSIS of 13.2 - 9.0 respectively, and as such implies that they are moderate risk factors that is acceptable but, requires suitable controls to maintain a safe working environment. Those ranked from $16^{\text {th }}$ to $21^{\text {st }}$ had RSIS of $7.9-6.4$ respectively, which implies low risk factors that are acceptable with no further action required. The factor "workers (erectors, dismantler) are leaving the work often due to hard working condition" had the lowest RSIS of 6.4 and does not really pose any treat to safety. This could be attributed to the high rate of unemployment in the country as reported by [24] thereby making the assertion in the factor false because, those who managed to be gainfully employed instead of leaving would rather do everything possible to keep their jobs so as to continue sustaining themselves. The fear that losing their job might make them become unemployed for the rest of their lives makes people stick to the ones they have irrespective of the working condition. It is widely recognised that poor maintenance culture is lacking in both private and public sectors in Nigeria as stated by [25]. This could therefore be the reason why "fracture of a wire rope during dismantling" closely followed by "Abrasion (wear and tear of components such as bolts, nuts or pins) had high RSIS of 15.6 and 13.2 respectively. Routine maintenance of the tower cranes could help to minimize the risk level. 
Table 4: Degree of impact

\begin{tabular}{|c|c|c|c|c|c|c|c|c|c|}
\hline \multirow{2}{*}{ S/No } & \multirow{2}{*}{ Safety Risk Factors } & \multicolumn{5}{|c|}{ Frequency } & \multirow{2}{*}{$\sum f$} & \multirow{2}{*}{$\begin{array}{l}\sum f x \\
\left(\sum \beta\right)\end{array}$} & \multirow{2}{*}{ Mean } \\
\hline & & 1 & 2 & 3 & 4 & 5 & & & \\
\hline 1 & Fracture of a wire rope during dismantling. & 0 & 0 & 1 & 12 & 25 & 38 & 176 & 4.63 \\
\hline 2 & $\begin{array}{l}\text { Not following work procedures in manuals for the } \\
\text { installation/climbing/dismantling of tower cranes. }\end{array}$ & 0 & 1 & 8 & 10 & 19 & 38 & 161 & 4.24 \\
\hline 3 & $\begin{array}{l}\text { Overloading with objects exceeding the tower crane } \\
\text { load limit. }\end{array}$ & 0 & 0 & 6 & 19 & 13 & 38 & 159 & 4.18 \\
\hline 4 & $\begin{array}{l}\text { Frequently omitting required safety procedures or } \\
\text { rules for various reasons. }\end{array}$ & 0 & 2 & 9 & 10 & 17 & 38 & 156 & 4.11 \\
\hline 5 & Lack of workers competence. & 0 & 3 & 8 & 12 & 15 & 38 & 153 & 4.03 \\
\hline 6 & $\begin{array}{l}\text { Unreasonable sites condition (working space, ground } \\
\text { conditions and restrictions). }\end{array}$ & 0 & 2 & 10 & 12 & 14 & 38 & 152 & 4.00 \\
\hline 7 & $\begin{array}{l}\text { Trying to finish the work earlier than the time required } \\
\text { for safe work. }\end{array}$ & 1 & 1 & 11 & 12 & 13 & 38 & 149 & 3.92 \\
\hline 8 & Inexperienced tower crane operators. & 1 & 5 & 6 & 11 & 15 & 38 & 148 & 3.89 \\
\hline 9 & Deterioration of tower cranes part (components). & 1 & 8 & 8 & 5 & 16 & 38 & 141 & 3.71 \\
\hline 10 & $\begin{array}{l}\text { Abrasion (wear and tear of components such as bolts, } \\
\text { nuts, or pins). }\end{array}$ & 1 & 4 & 17 & 2 & 14 & 38 & 138 & 3.63 \\
\hline 11 & Malfunction of a tower crane. & 1 & 3 & 16 & 8 & 10 & 38 & 137 & 3.61 \\
\hline 12 & Incompatibility of components. & 1 & 11 & 5 & 9 & 12 & 38 & 134 & 3.53 \\
\hline 13 & Buckling of a telescopic cage. & 0 & 8 & 9 & 16 & 5 & 38 & 132 & 3.47 \\
\hline 14 & Falling items. & 1 & 8 & 9 & 18 & 2 & 38 & 126 & 3.32 \\
\hline 15 & $\begin{array}{l}\text { Contractors do not recognise the need to ensure the } \\
\text { safety of tower crane installation and dismantling. }\end{array}$ & 1 & 10 & 13 & 6 & 8 & 38 & 124 & 3.26 \\
\hline 16 & Failure of working platforms. & 5 & 6 & 7 & 15 & 5 & 38 & 123 & 3.24 \\
\hline 17 & $\begin{array}{l}\text { Instruction and supervision at construction sites are } \\
\text { insufficient. }\end{array}$ & 5 & 6 & 13 & 10 & 4 & 38 & 116 & 3.05 \\
\hline 18 & $\begin{array}{l}\text { Insufficient number of workers to perform the work } \\
\text { correctly and safely. }\end{array}$ & 5 & 2 & 23 & 7 & 1 & 38 & 111 & 2.92 \\
\hline 19 & $\begin{array}{l}\text { Time constraints requested from employer/principal } \\
\text { contractor. }\end{array}$ & 2 & 16 & 10 & 9 & 1 & 38 & 105 & 2.76 \\
\hline 20 & Workers attitude (installation/dismantling workers). & 2 & 17 & 9 & 9 & 1 & 38 & 104 & 2.74 \\
\hline 21 & $\begin{array}{l}\text { Workers (erector, dismantler) are leaving the work } \\
\text { often due to hard working condition). }\end{array}$ & 6 & 21 & 6 & 2 & 3 & 38 & 89 & 2.34 \\
\hline
\end{tabular}

$1=$ Negligible $2=$ Minor Injury $3=$ Major Injury $4=$ Fatality and $5=$ Multiple Fatality.

Table 5: Safety risk evaluation

\begin{tabular}{lllllllll}
\hline S/No. & Safety Risk Factors & $\sum a$ & $\sum \beta$ & $\sum$ RS & $N$ & RSIS & Rank & $\begin{array}{l}\text { Risk } \\
\text { Level }\end{array}$ \\
\hline 1 & Fracture of a wire rope during dismantling. & 128 & 176 & 22528 & 1444 & 15.6 & $1^{\text {st }}$ & High \\
2 & $\begin{array}{l}\text { Abrasion (wear and tear of components such as bolts, nuts, } \\
\text { or pins). }\end{array}$ & 138 & 138 & 19044 & 1444 & 13.2 & $2^{\text {nd }}$ & Moderate \\
3 & Lack of workers competence. & 119 & 153 & 18207 & 1444 & 12.6 & $3^{\text {rd }}$ & Moderate \\
4 & Inexperienced tower crane operators. & 121 & 148 & 17908 & 1444 & 12.4 & $4^{\text {th }}$ & Moderate \\
5 & $\begin{array}{l}\text { Not following work procedures in manuals for the } \\
\text { installation/climbing/dismantling of tower cranes. }\end{array}$ & 110 & 161 & 17710 & 1444 & 12.3 & $5^{\text {th }}$ & Moderate
\end{tabular}




\begin{tabular}{|c|c|c|c|c|c|c|c|c|}
\hline S/No. & Safety Risk Factors & $\sum a$ & $\Sigma \beta$ & $\sum \mathrm{RS}$ & $\mathrm{N}$ & RSIS & Rank & $\begin{array}{l}\text { Risk } \\
\text { Level }\end{array}$ \\
\hline 6 & Deterioration of tower cranes part (components). & 125 & 141 & 17625 & 1444 & 12.2 & $6^{\text {th }}$ & Moderate \\
\hline 7 & $\begin{array}{l}\text { Frequently omitting required safety procedures or rules for } \\
\text { various reasons. }\end{array}$ & 111 & 156 & 17316 & 1444 & 12.0 & $7^{\text {th }}$ & Moderate \\
\hline 8 & $\begin{array}{l}\text { Trying to finish the work earlier than the time required for } \\
\text { safe work. }\end{array}$ & 116 & 149 & 17284 & 1444 & 12.0 & $8^{\text {th }}$ & Moderate \\
\hline 9 & $\begin{array}{l}\text { Unreasonable sites condition (working space, ground } \\
\text { conditions and restrictions). }\end{array}$ & 99 & 152 & 15048 & 1444 & 10.4 & $9^{\text {th }}$ & Moderate \\
\hline 10 & Buckling of a telescopic cage. & 112 & 132 & 14784 & 1444 & 10.2 & $10^{\text {th }}$ & Moderate \\
\hline 11 & Falling items. & 111 & 126 & 13986 & 1444 & 9.7 & $11^{\text {th }}$ & Moderate \\
\hline 12 & Failure of working platforms. & 111 & 123 & 13653 & 1444 & 9.5 & $12^{\text {th }}$ & Moderate \\
\hline 13 & $\begin{array}{l}\text { Contractors do not recognise the need to ensure the safety } \\
\text { of tower crane installation and dismantling. }\end{array}$ & 110 & 124 & 13640 & 1444 & 9.4 & $13^{\text {th }}$ & Moderate \\
\hline 14 & $\begin{array}{l}\text { Overloading with objects exceeding the tower crane load } \\
\text { limit. }\end{array}$ & 84 & 159 & 13356 & 1444 & 9.2 & $14^{\text {th }}$ & Moderate \\
\hline 15 & Malfunction of a tower crane. & 95 & 137 & 13015 & 1444 & 9.0 & $15^{\text {th }}$ & Moderate \\
\hline 16 & $\begin{array}{l}\text { Insufficient number of workers to perform the work correctly } \\
\text { and safely. }\end{array}$ & 103 & 111 & 11433 & 1444 & 7.9 & $16^{\text {th }}$ & Low \\
\hline 17 & Incompatibility of components. & 82 & 134 & 10988 & 1444 & 7.6 & $17^{\text {th }}$ & Low \\
\hline 18 & $\begin{array}{l}\text { Time constraints requested from employer/principal } \\
\text { contractor. }\end{array}$ & 99 & 105 & 10395 & 1444 & 7.2 & $18^{\text {th }}$ & Low \\
\hline 19 & $\begin{array}{l}\text { Instruction and supervision at construction sites are } \\
\text { insufficient. }\end{array}$ & 89 & 116 & 10324 & 1444 & 7.1 & $19^{\text {th }}$ & Low \\
\hline 20 & Workers attitude (installation/dismantling workers). & 94 & 104 & 9776 & 1444 & 6.8 & $20^{\text {th }}$ & Low \\
\hline 21 & $\begin{array}{l}\text { Workers (erector, dismantler) are leaving the work often due } \\
\text { to hard working condition). }\end{array}$ & 104 & 89 & 9256 & 1444 & 6.4 & $21^{\text {st }}$ & Low \\
\hline
\end{tabular}

\section{CONCLUSION AND FURTHER RESEARCH}

The study concludes that abrasion (wear and tear of components such as bolts, nuts, or pins) was the most probable factor and fracture of a wire rope during dismantling had the highest degree of impact. In evaluating the safety risk factors, "fracture of a wire rope during dismantling and abrasion (wear and tear of components such as bolts, nuts, or pins) which could both be seen as a maintenance management issue as looked at by previous research is a highly affecting factor on safety during installation and dismantling. Adoption of a preventive maintenance strategy or routine check on the tower crane parts and components could help minimize the probability of occurrence and impact of the safety risk factors on site during installation and dismantling of tower cranes.

\section{REFERENCES}

[1] Beavers, J.E., Moore, J.R., Rinehart, R., and Schriver, W.R. Crane-related fatalities in construction industry, Journal of Construction Engineering and Management, Vol. 132, Number 9, pp 901-910, 2006.

[2] Bureau of Labour Statistics (BLS). Crane-Related Occupational Fatalities, United States, Fact Sheet BLS, 2008.

[3] Annex, B. Crane safety analysis and recommendation report. Workplace Safety and Health Council, the Ministry of Manpower and the National Crane Safety Taskforce, Singapore, 2009.

[4] Idoro, G. I. Health and safety management efforts as correlates of performance in the Nigeria construction industry, Journal of Civil Engineering and Management, Vol. 14, Number 4, pp 277-285, 2008. 
[5] Orji, S.E., Enebe, E.C., \& Onoh, F.E. Accidents in building construction sites in Nigeria; a case of Enugu state, International journal of innovative research and development, Vol. 5, Number 4, pp 244-248, 2016.

[6] Chen, W.T., Lu, C.S., \& Huang, Y. Investigating the safety cognition of Taiwan's construction personnel, Journal of Marine Science and Technology, Vol. 19, Number 4, pp 398-408, 2011.

[7] Ali, M.K.A.M., \& Muhamad, M.I. Crane Failure and Accident in Construction. Faculty of Civil Engineering, Universiti Teknologi Malaysia, Malaysia, 2016.

[8] Nunnally, S.W. Managing construction equipment, (2nd ed.). Upper Saddle River, New Jersey, Prentice-Hall, 2000.

[9] Shapira, A., \& Lyachin, B. Identification and analysis of factors affecting safety on construction sites with tower cranes. Journal of Construction Engineering and Management, Vol. 135, Number 1, pp 24-33, 2009.

[10] Idoro, G.I. Effect of Mechanization on Occupational Health and Safety Performance in the Nigerian Construction Industry, Journal of Construction in Developing Countries, Vol. 16, Number 2, pp 27-45, , 2011.

[11] Kadiri, Z.O., Nden, T., Avre, G.K., Oladipo, T.O., Edom, A., Samuel, P.O., \& Ananso, G.N. Causes and Effects of Accidents on Construction Sites (A Case Study of Some Selected Construction Firms in Abuja F.C.T Nigeria), IOSR Journal of Mechanical and Civil Engineering, Vol.11, Number 5, pp 66-72, 2014.

[12] Safework. Erection, climbing and dismantling tower cranes. Industry plant consultative committee, New South Wales, Australia, October 31, 2016.

[13] Occupational Safety and Health Administration (OSHA). Region 6 News Release: 12-2231$D A L$, United States, November 20, 2012.

[14] Ting, F. "The promotion strategy of occupational health and safety by government." Annual meeting of Hong Kong Construction Association Limited, Hong Kong, 2007.

[15] Zhao, Q. Cause analysis of US crane-related accidents, MSc Dissertation, Graduate School of the University of Florida USA, 2011.
[16] Shin, I. J. Factors that affect safety of tower crane installation/dismantling in construction industry, Journal of Safety Science, Vol. 72, Number 2015, pp 379-390, 2015.

[17] Chi, S., Sangwon, H., Dae Y.K., \& Yoonjung, S. Accident risk identification and its impact analyses for strategic construction safety management, Journal of Civil Engineering and Management, Vol. 21, Number 4, pp 524-538, 2015.

[18] Jannadi, O.A., \& Almishari, S. Risk assessment in construction. Journal of Construction Engineering and Management, Vol. 129, Number 5, pp 492-500, 2003.

[19] Odeyinka, H.A., and Dada J.O. Risk assessment and allocation in budgeting. $A$ paper delivered at the Nigerian Institute of Quantity Surveyors (NIQS) Workshop at Precious Conference Centre Makurdi, Benue State, July 27-28, 2016.

[20] Salihu, A.A., Aliyu, S.S., \& Abubakar, M. An assessment of safety risk factors during installation and dismantling of tower cranes in construction sites, MSc Dissertation, Building Department, Ahmadu Bello University Zaria, Kaduna State, 2018.

[21] Louangrath, P.T.I. Sample Size Determination for Non-Finite Population. International Conference on Discrete Mathematics and Applied Sciences (ICDMAS), University of Thai Chamber of Commerce Conference Proceedings, Applied Science Section, 2014, Article No. 2.

[22] Shapiro, H., Shapiro, J., \& Shapiro, K. Cranes and Derricks, McGraw-Hill, New York, 2000.

[23] Construction Plant Hire Association (CPA). The climbing of tower cranes CPA Best practice guide, Published by tower crane interest group (TCIG), London, United Kingdom, 2011.

[24] National Bureau of Statistics (NBS). Labour Force Statistics Vol: 1 Unemployment and Underemployment Report. Q1 - Q3, 5. Nigeria, 2017.

[25] Mbamali, I. The impact of accumulation of deferred maintenance on selected buildings of two federal universities in the northwest zone of Nigeria. Journal of Environmental Sciences. Vol. 5, Number 1, pp 77-83, 2003 